Finally it should be mentioned that practical arrangements to meet the rapid increase in the pressure of work which already has been felt, and can be expected to continue, as a result of the passing of the act on mineral resources, have been under consideration.

K. Ellitsgaard-Rasmussen Director

\title{
NOTES ON THE PRECAMBRIAN TO LOWER CAMBRIAN STRATIGRAPHY OF THE SOUTH-EASTERN PART OF HEILPRIN LAND, INDEPENDENCE FJORD, NORTH GREENLAND
}

\section{Hans F. Jepsen}

As a member of the 7th Danish Peary Land Expedition in the summer of 1970 led by Count Eigil Knuth, the author had the opportunity to study a section through the Precambrian, Eocambrian and Lower Cambrian strata along the south-eastern shore of Heilprin Land (fig. 2). The main purpose was to examine the Precambrian Midsommersø dolerites (see below), and also to map the sedimentary formations of the area. This report describes the results of the mapping.

In 1966 and 1968 the area west and north-west of Independence Fjord around Jørgen Brønlund Fjord and Midsommersøerne was mapped (Jepsen, 1969). The approx. $1000 \mathrm{~m}$ thick sedimentary sequence below the Lower Cambrian Brønlund Fjord Dolomite (Troelsen, 1949, pp. 13-15) was divided into four formations (Jepsen, in press) - in ascending order: Inuiteq Sø Formation (sandstone, at least $230 \mathrm{~m}$, Precambrian), Morænesø Formation (tillite and dolomite, 0 to $117 \mathrm{~m}$, Eocambrian), Portfjeld Formation (dolomite, $206 \mathrm{~m}$ at the type locality, Eocambrian or Lower Cambrian), Buen Formation (sandstone and shale, $425 \mathrm{~m}$ at the type locality, Lower Cambrian). The first three named formations are separated by unconformities both of which represent long erosion periods. The strata are cut by two dolerite sequences of which the oldest (the Midsommersø dolerites) is of Precambrian age and intrudes only the Inuiteq Sø Formation. Intrusions of the youngest sequence penetrate all the strata in the area and are regarded as post-Palaeozoic. With a nearly constant thickness ( $575 \mathrm{~m}$ to $631 \mathrm{~m}$ total) the Portfjeld and Buen Formations were found to be distributed over the whole mapped area, which is about $2500 \mathrm{~km}^{2}$ with an east-west extent just under $90 \mathrm{~km}$ (Jepsen, in press, plate 1).

In 1970 this stratigraphy was followed south-westwards along the shore of Heilprin Land (fig. 2). Here again, the oldest beds belong to the Precambrian Inuiteq Sø Formation, which west of Kap Ejnar Mikkelsen attains a thickness of at least $800 \mathrm{~m}$. 
Since the intrusion of the Midsommersø dolerites has disturbed the flat-lying beds and since most of the formation is scree-covered, it was not possible to measure a regional direction of dip. At the beginning of the Eocambrian the area became icecovered, and during that glaciation a rather irregular topography was developed on the upper surface of the Inuiteq Sø Formation (Jepsen, in press). This erosional surface has a slight dip $\left(1-2^{\circ}\right)$ towards NNE with the result that it reaches the mountain plateau (about $750 \mathrm{~m}$ above sea level) north-west of Diabasnæs and that south of latitude $82^{\circ}$ all the strata exposed belong to the Inuiteq Sø Formation. The Eocambrian ice deposited the tillite found in the lower part of the Morænesø Formation, and later on the Inuiteq Sø Formation was transgressed by the Eocambrian and Lower Cambrian sea, but dry land still existed towards the south during at least part of the Lower Cambrian. This development has resulted in incomplete representation of the Eocambrian and Lower Cambrian strata along the south-eastern shore of Heilprin Land. Both the Morænesø and Portfjeld Formations wedge out towards the south. The Buen Formation, which forms the uppermost beds south of Jørgen Brønlund Fjord, is resting directly upon the Inuiteq Sø Formation on the plateau north-west of Diabasnæs. Because of the present level of erosion nothing can be said about the southward extent of the Buen Formation during the Lower Cambrian.

The conclusion to be drawn from the depositional evolution outlined above must be that the coast-line of the Eocambrian and Lower Cambrian sea ran E-W across Heilprin Land and that if the southern part of Heilprin Land has been submerged since the Precambrian it must have been relatively late in the history of the area. That the coast line at the beginning of the Cambrian ran across Heilprin Land was first postulated by Koch (1929, p. 273).

\section{References}

Jepsen, H. F. 1969: Preliminary report on the stratigraphy of the Precambrian and Eocambrian sediments in the Jørgen Brønlund Fjord - Midsommersø area, southern Peary Land. Rapp. Gronlands geol. Unders. 19, 11-14.

Jepsen, H. F. (in press): The Precambrian, Eocambrian and early Palaeozoic stratigraphy of the Jørgen Brønlund Fjord area, Peary Land, North Greenland. Bull. Gronlands geol. Unders. (also Meddr Gronland 192, 2).

Koch, L. 1929: Stratigraphy of Greenland. Meddr Grønland 73, Afd. 2, 205-320.

Troelsen, J. C. 1949: Contributions to the geology of the area round Jørgen Brønlunds Fjord, Peary Land, North Greenland. Meddr Greenland 149, 2, 29 pp. 